\title{
Molecular Confirmation that Sterile Cytoplasm Has Been Introduced into Open-pollinated Grano Onion Cultivars
}

\author{
M.J. Havey ${ }^{1}$ and O.H. Bark ${ }^{2}$ \\ Vegetable Crops Unit, Agricultural Research Service, U.S. Department of Agriculture, Department of \\ Horticulture, University of Wisconsin, Madison, WI 53706 \\ Additional index words. chloroplast DNA, cytoplasmic male sterility, introgression, RFLPs
}

\begin{abstract}
Open-pollinated (OP) onion (Allium cepa L.) cultivars are primarily in normal (N) fertile cytoplasm; however, specific cultivars possess both $N$ and sterile $(S)$ cytoplasm or are exclusively in $S$ cytoplasm. It is unclear whether the presence of $\mathbf{S}$ cytoplasm in OP cultivars is due to ancient or recent introduction or both. Restriction-enzyme analysis of the chloroplast DNA established that $S$ cytoplasm has been introgressed into OP onion cultivars since its discovery in 1925. 'Valencia Grano' (released in 1927), 'New Mexico Early Grano' (1931), 'Texas Early Grano (TEG) 502' (1947), and 'Temprana' (1979) are in $N$ cytoplasm; $S$ cytoplasm was introduced into the population 'TEG 502 PRR', and subsequent selections ('NuMex BR1' and 'NuMex Sunlite') are in S cytoplasm. The inbred 'TEG 951 C' and 'Texas Grano 1015Y' possess a mixture of $\mathrm{N}$ and $\mathrm{S}$ cytoplasm and, because these two onions originated from self-pollinations of single plants, bulb or seed mixtures or both must have occurred.
\end{abstract}

Cytoplasmic-genie male sterility (CMS) systems are used to produce hybrid onion seed (Pike, 1986). Sterile (S) cytoplasm was discovered in 1925 (Jones and Emsweller, 1936) and is the most commonly used source of S cytoplasm. Normal (N) fertile and S cytoplasm are distinguishable by restriction-enzyme (RE) analysis of the chloroplast genome (de Courcel et al., 1989; Havey, 1993; Holford et al., 1991). We have reported that open-pollinated (OP) onion cultivars possess $\mathrm{N}$ and $\mathrm{S}$ cytoplasm (Havey, 1993). It is unclear whether the presence of $\mathrm{S}$ cytoplasm in OP cultivars is due to ancient introgression or introduction since its discovery. Because fertility can be restored by a dominant allele at a single nuclear restorer locus, Ms (Jones and Clarke, 1943), S cytoplasm may be introduced into an OP population with a high frequency of the restorer allele (Davis, 1957; Little et al., 1944) and sterile plants may rarely segregate. We undertook this study to determine if $\mathrm{S}$ cytoplasm had been introduced into onion cultivars since its discovery in 1925.

\section{Materials and Methods}

We obtained accessions of onion cultivars of known phylogeny (Fig. 1, Table 1). Inbreds B3350 A (S cytoplasm) and B3350 B (N cytoplasm) were used as controls. Allium fistulosum L. 'Ishikura' was also included; interspecific hybrids with the bulb onion have been generated (Emsweller and Jones, 1935) and the possibility exists that $A$. fistulosum cytoplasm has been introduced into OP onion cultivars. Procedures for isolating genomic DNA from at least 100 seedlings, RE digestions, electrophoresis, blotting, nick translation, and hybridization of clones from the chloroplast genome of the orchid Oncidium excavatum (Chase and Palmer,

Received for publication 26 Feb. 1993. Accepted for publication 14 May 1993. Use of trade names does not imply endorsement of the products named nor criticism of similar ones not named, We are grateful to Mark Chase (Univ. of North Carolina) for the orchid chloroplast clones and to Joe Corgan (New Mexico State Univ.), Rick Jones (Asgrow), Ivan Miller (SunSeeds), and Leonard Pike (Texas A\&M Univ.) for onion seed and helpful discussions. The cost of publishing this paper was defrayed in part by the payment of page charges. Under postal regulations, this paper therefore must be hereby marked advertisement solely to indicate this fact.

'Research geneticist and assistant professor,

'Graduate research assistant.
1989), and autoradiography have been reported (Havey, 1991 b). We distinguished $\mathrm{N}$ and $\mathrm{S}$ cytoplasm by the characters chloroplast (cp) DNA 1 (orchid clones 3,4, and 6a hybridized to $B g l$ II digests), 2 and 4 (clones $12 \mathrm{~b}$ and c hybridized to $B g l$ II and Eco RV digests, respectively), and 41 (clones 19 a and b hybridized to Bam HI digests). Characters cpDNA 1,2, and 41 represent gains of RE sites by $\mathrm{S}$ cytoplasm; cpDNA 4 is the gain of an Eco RV site by $\mathrm{N}$ cytoplasm (Havey, 1993). S and A. fistulosum cytoplasm are distinguished by the autapormorphic gain of cpDNA 41 in $\mathrm{S}$ cytoplasm. For cultivars possessing $\mathrm{N}$ and $\mathrm{S}$ cytoplasm, the proportion of each cytoplasm was estimated by densitometric scanning ( $\lambda=500 \mathrm{~nm}$ ), which compared the relative intensities of bands in single lanes of autoradiograms (Havey, 1993).

\section{Results and Discussion}

Maternal inheritance of cpDNA in onion has been demonstrated (Corriveau and Coleman, 1988; Tatabe, 1968). Although we know of no transmission studies for the onion mitochondrial (ret) DNA, maternal inheritance must predominate, as CMS is maintained across many genetic backgrounds. Jones and Clarke (1943) self-pollinated individual plants in S cytoplasm with fertility restored by the dominant nuclear allele $(S M s m s)$ and observed segregation for sterility, a result indicating that fertility restoration

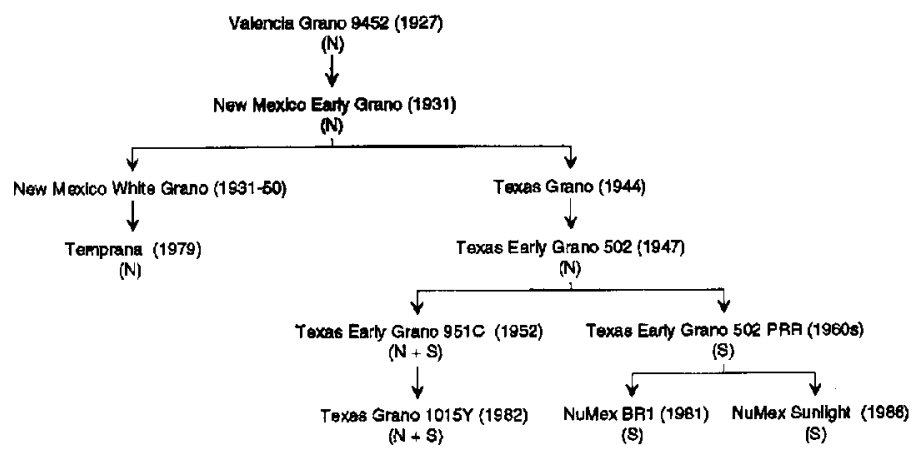

Fig. 1. Pedigrees of Grano-type onions (adapted from Corgan, 1984, 1988; Enzie and Corgam, 1979; Pike et al., 1988). We established cytoplasm as normal (N) fertile or sterile (S) by restriction-enzyme analysis of the chloroplast DNA. 
Table 1. Origin and cytoplasm of onion inbreds and open-pollinated cultivars.

\begin{tabular}{|c|c|c|c|c|}
\hline Inbred or cultivar $^{2}$ & Lot & Source $^{y}$ & Location & Cytoplasm \\
\hline$\overline{\mathrm{B} 3350 \mathrm{~A}}$ & $909-1$ & USDA & Madison, Wis. & Sterile (S) \\
\hline $\mathrm{B} 3350 \mathrm{~B}$ & $909-2$ & USDA & Madison & Normal (N) \\
\hline Valencia Grano $^{x}$ & S91A519 & Asgrow & Arvin, Calif. & $\mathrm{N}$ \\
\hline \multirow[t]{2}{*}{ New Mexico Early Grano } & Unknown & Arco, SunSeeds & El Centro, Calif. & $\mathrm{N}$ \\
\hline & SVG V 2012 & Asgrow & Arvin & $\mathrm{N}$ \\
\hline \multirow[t]{4}{*}{$\mathrm{TEG}^{\mathrm{w}} 502$} & SPN 112 & Asgrow & Arvin & $\mathrm{N}$ \\
\hline & SPN 118 & Asgrow & Arvin & $\mathrm{N}$ \\
\hline & SPN 122 & Asgrow & Arvin & $\mathrm{N}$ \\
\hline & SUGJ 1043 & Asgrow & Arvin & $\mathrm{N}$ \\
\hline \multirow[t]{3}{*}{ TEG $951 \mathrm{C}$} & 1978 & SunSeeds & El Centro, Calif. & $\mathrm{S}$ and $\mathrm{N}$ \\
\hline & 1981 & SunSeeds & El Centro, Calif. & $\mathrm{S}$ and $\mathrm{N}$ \\
\hline & 1984 & SunSeeds & El Centro, Calif. & Sand N \\
\hline \multirow[t]{6}{*}{ TEG 502 PRR } & Second & SunSeeds & El Centro, Calif. & $\mathrm{s}$ \\
\hline & Research & SunSeeds & El Centro, Calif. & $\mathrm{s}$ \\
\hline & VGC 3051 & Asgrow & Arvin, Calif. & $\mathrm{s}$ \\
\hline & 80354-329 & Peto & Woodland, Calif. & $\mathrm{s}$ \\
\hline & Unknown & Peto & Woodland & $\mathrm{s}$ \\
\hline & VGM 6402 & Asgrow & Arvin & $\mathrm{s}$ \\
\hline \multirow[t]{2}{*}{ NuMex Sunlite } & Unknown & NMSU & Las Cruces, NM & $\mathrm{s}$ \\
\hline & 8919 & NMSU & Las Cruces & $\mathrm{s}$ \\
\hline NuMex BR-1 & Unknown & NMSU & Las Cruces & s \\
\hline \multirow[t]{3}{*}{$\mathrm{TG}^{\mathrm{v}} 1015 \mathrm{Y}$} & $80355-331$ & Peto & Woodland & Sand N \\
\hline & VGS 9090 & Asgrow & Arvin & Sand N \\
\hline & Unknown & Texas A\&M & College Station, Texas & Sand N \\
\hline Temprana & Unknown & NMSU & Las Cruces & $\mathrm{N}$ \\
\hline Ishikura & A. fistulosum & NMSU & Las Cruces & Fistulosum \\
\hline
\end{tabular}

${ }^{7}$ Control inbreds are B3350 A (S cytoplasm) and B3350 B (N cytoplasm).

${ }^{y}$ USDA = United States Dept. of Agriculture, Vegetable Crops Unit; NMSU = New Mexico State Univ.

${ }^{x}$ Valencia Grano is a synonym for Babosa (Magruder et al., 1941).

"TEG = Texas Early Grano.

"TG $=$ Texas Grano.

is not the result of a mixture of organelles from $\mathrm{N}$ and $\mathrm{S}$ cytoplasm. We used polymorphic RE sites in cpDNA to document the introduction and distribution of $\mathrm{S}$ cytoplasm in OP cultivars because of its strict maternal inheritance. However, we recognize that occasional biparental transmission of mtDNA would generate individual plants with a mixture of mitochondria from $\mathrm{N}$ and $\mathrm{S}$ cytoplasm.

Characters cpDNA 1,2,4, and 41 established that S cytoplasm has been introduced into OP onion cultivars since its discovery in 1925. 'Valencia Grano' (released in 1927), 'New Mexico Early Grano' (1931), 'Texas Early Grano (TEG) 502' (1947), and 'Temprana' "(1979) are in N cytoplasm; S cytoplasm was introduced into 'TEG 502 PRR' (1960s), and subsequent selections ('NuMex BR1' and 'NuMex Sunlite') are now exclusively in S cytoplasm (Figs. 1-3). It is also possible that 'TEG 502' possesses $\mathrm{S}$ cytoplasm at a low frequency and the bulbs selected to generate 'TEG 502 PRR' were S cytoplasmic. This latter scenario is unlikely, since no evidence of S cytoplasm was detected in four 'TEG 502' strains (Table 1). It is also unlikely that $\mathrm{S}$ cytoplasm was introduced into 'TEG 502', which was selected in 1947 before the 1952 release of the first sterile short-day inbreds (L690 A and YB986 A).

'TEG 502 PRR' was developed as a pink-root-resistant cultivar by Henry Jones and first appeared in Dessert-Seed catalogs in the early 1960s. A source of pink-root resistance available at that time was 'Excel 986', a cultivar developed earlier by Jones (Jones and Clarke, 1946). If Jones used the sterile inbred YB986 A (derived by backcrossing S cytoplasm to 'Excel 986') in crosses with Grano types (i.e., derived from the original introduction of 'Valencia Grano'), it is conceivable that he could have selected for the pinkroot resistance of 'Excel 986' and the rounder bulbs of 'TEG 502'. The F, plants would be fertile ( $S$ Msms) because Grano cultivars possess the nuclear restorer at a high frequency (Little et al., 1944). Jones may have self-pollinated or sib-mated $F_{1}$ plants to identify progeny not segregating for fertility; i.e., homozygous dominant at the nuclear restorer locus ( $S M s M s$ ).

Inbred 'TEG951 C', originated from the self-pollination of a single bulb of 'TEG 502' (Havey, 1991a), was released in 1952 and is the pollinating line of the hybrid Granex ( 'YB986 A' × 'TEG 951 C'). 'Texas Grano (TG) $1015 \mathrm{Y}$ ' is a single bulb selection out of 'TEG 951 C' (Pike et al., 1988). However, these two onions possess N and S cytoplasm (Fig. 2, Table 1). Densitometric scans estimated the proportion of S cytoplasm to be $\approx 30 \%$ and $85 \%$ in 'TEG951 C' and 'TG 1015 Y', respectively. This anomaly illustrates the problem of cytoplasmic contamination by mixing seeds or bulbs or both during the cultivars' increases. Jones' original 'TEG951 C' selection was likely in N cytoplasm, and S cytoplasm must have been introduced by mixtures of bulbs, seeds, or both. 'TEG $951 \mathrm{C}$ ' was homozygous dominant at the nuclear restorer locus (as evidenced by uniform restoration of fertility on sterile lines), and S cytoplasm could have been consciously or inadvertently introduced without the immediate appearance of sterile plants. Conversely, 'TG $1015 \mathrm{Y}$ ' likely originated from the selfpollination of a single bulb in restored S cytoplasm ( $S M s M s$ ), and $\mathrm{N}$ cytoplasm was introduced later. A second scenario is that 'TG 1015Y' was selected from 'TEG 502 PRR' and not 'TEG951 C'. 


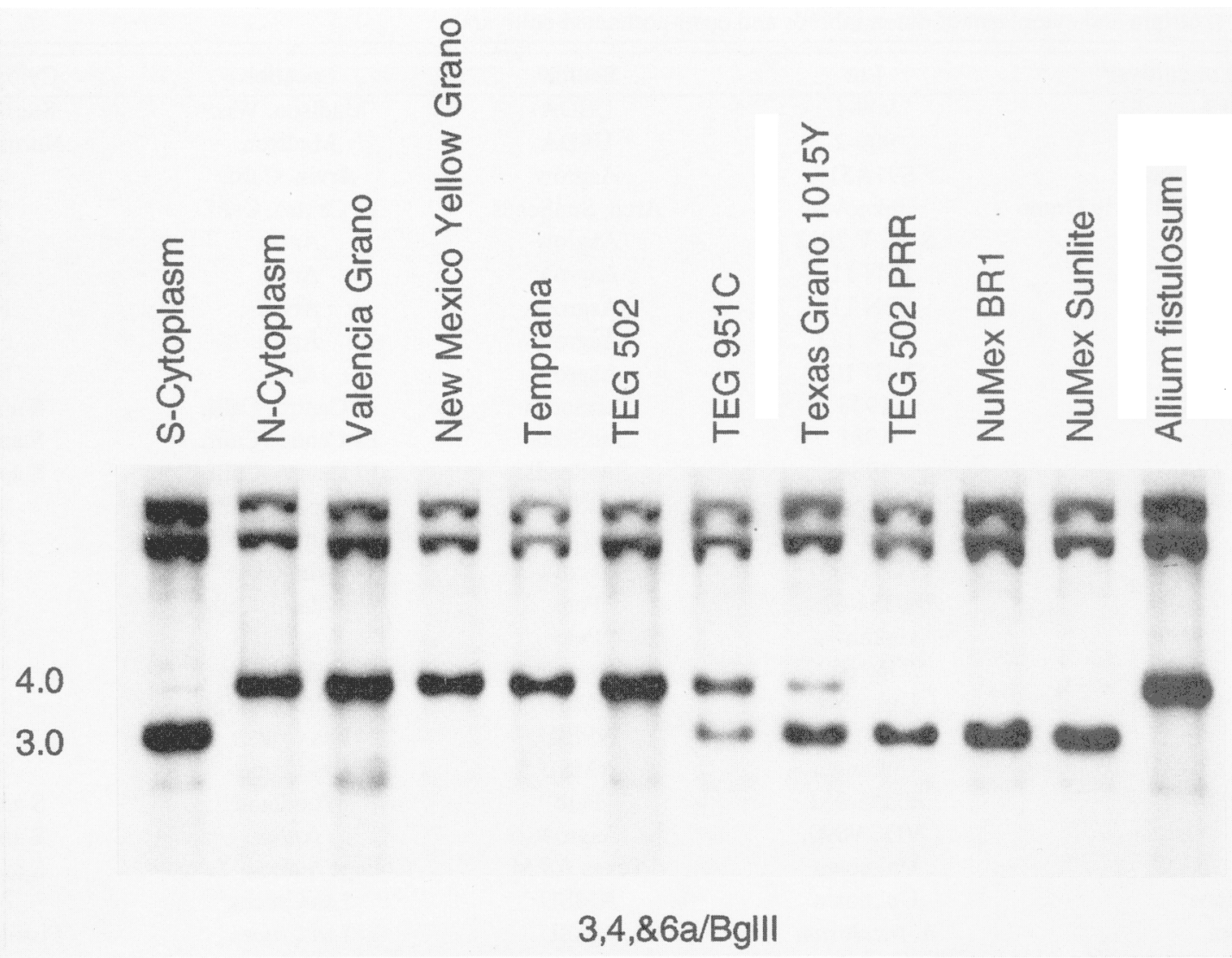

Fig. 2. Sterile (S) cytoplasm in onion cultivars is demonstrated by the presence of the 3.0-kbase band. Lanes contain Bgl II-digested DNA hybridized with the orchid chloroplast clones 3,4, and 6a. Note that 'Texas EarlyGrano 951 C' and 'Texas Grano 1015Y' possess chloroplast DNA from normal (N) and S cytoplasm.

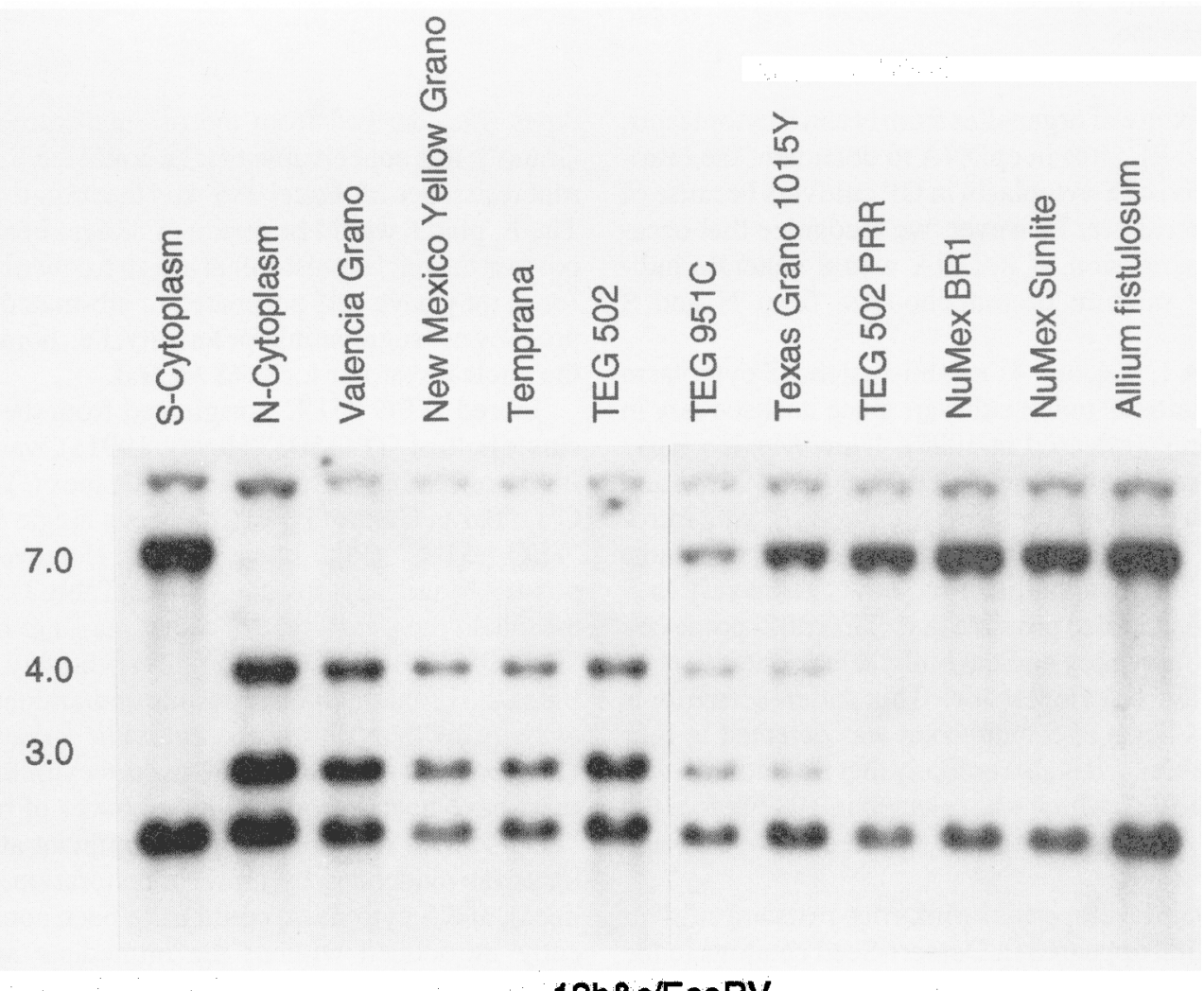

\section{2b\&c/EcoRV}

Fig. 3. Normal cytoplasm in onion cultivars is demonstrated by the presence of the 3.0- and 4.0-kbase bands. Lanes contain EcoRV-digested DNA hybridized with orchid chloroplast clones $12 \mathrm{~b}$ and $\mathrm{c}$. 
This latter possibility is supported by the fact that ' $T G 1015 \mathrm{Y}$ ' shows significantly more pink-root resistance than 'TEG 502' and 'TEG 951 C' (Pike et al., 1988).

Our research documents the introduction of $\mathrm{S}$ cytoplasm into Grano cultivars, the principle American short-day onion. Breeders have attempted to extract maintainer lines from cultivars such as 'NuMex Sunlite' or 'TG $1015 \mathrm{Y}$ ' by pairing randomly selected fertile plants with sterile plants. Obviously, such an approach will rarely succeed because fertile plants are most likely in restored sterile cytoplasm. The results presented here illustrate the importance for onion breeders to determine the type of cytoplasm, either with molecular or classical methods, before attempting to extract maintainer lines from an uncharacterized OP population.

\section{Literature Cited}

Chase, M. and J. Palmer. 1989. Chloroplast DNA systematic of lilioid monocots, feasibility, resources, and an example from the Orchidaceae. Amer. J. Bot. 76(12):1720-1730.

Corgan, J.N. 1984. 'NuMex BR1' onion. HortScience 19:593.

Corgan, J.N. 1988. 'NuMex Sunlite' onion. HortScience 23:423-424.

Corriveau, J. and A. Coleman. 1988. Rapid screening method to detect biparental inheritance of plastid DNA and results from over 200 angiosperm species. Amer. J. Bot 75(10):1443-1458.

Davis, E. 1957. The distribution of the male-sterility gene in onion. J. Amer. Soc. Hort. Sci. 70:316-318.

de Courcel, A., F. Vedel, and J. Boussac. 1989. DNA polymorphism in Allium cepa cytoplasm and its implications concerning the origin of onions. Theoretical Applied Genet. 77:793-798.

Emsweller, S.L. and H.A. Jones. 1935. An interspecific hybrid in Allium. Hilgardia 9:265-273.
Enzie, J.V. and J.N. Corgan. 1979. 'Temprana', an early maturing white Grano onion. New Mexico State Univ. Circ. 488.

Havey, M. 199 la. History of releases from the onion-breeding program of the United States Department of Agriculture. Allium Nwsl. 1:50-54

Havey, M. 1991b. Phylogenetic relationships among cultivated Allium species from restriction enzyme analysis of the chloroplast genome. Theoretical Applied Genet. 81:752-757.

Havey, M. 1993. A putative donor of S-cytoplasm and its distribution among open-pollinated populations of onion. Theoretical Applied Genet. 86:128-134.

Holford, P., J. Croft, and H. Newbury. 1991. Differences between, and possible origins of, the cytoplasm found in fertile and male-sterile onions (Allium cepa L.). Theoretical Applied Genet. 82:737-744.

Jones, H. and A. Clarke. 1943. Inheritance of male sterility in the onion and the production of hybrid seed. Proc. Amer. Soc. Hort. Sci. 43: 189-194.

Jones, H. and A. Clarke. 1946. Annual report of the national onionbreeding program. Plant Ind. Sta., Beltsville, Md. p. 2-3.

Jones, H. and S. Emsweller. 1936. A male sterile onion. Proc. Amer. Soc. Hort. Sci. 34:582-585.

Little, T., H. Jones, and A. Clarke. 1944. The distribution of the malesterility gene in varieties of onion. Herbertia 11:310-312.

Magruder, R., R. Webster, H. Jones, T. Randall, G. Snyder, H. Brown, L. Hawthorn, and A. Wilson. 1941, Descriptions of types of principal American varieties of onions. U.S. Dept. of Agr., Washington, DC. Misc. Publ. 435.

Pike, L. M., 1986. Onion breeding, p. 357-394. In: M. Bassett (cd.). Breeding vegetable crops. AVI, Westport, Corm.

Pike, L. M., R.S. Horn, C.R. Andersen, P.W. Leeper, and M.E. Miller. 1988. 'Texas Grano 1015 Y': A mild pungency, sweet, short-day onion. HortScience 23:634-635.

Tatabe, T. 1968. Genetic studies on the leaf variegation of Allium cepa $\mathrm{L}$. J. Jpn. Soc. Hort. Sci. 37:345-348. 